\title{
Winter wave climate, storms and regional cycles: the SW Spanish Atlantic coast
}

\author{
N. Rangel-Buitrago* and G. Anfuso \\ Departamento de Ciencias de la Tierra, Facultad de Ciencias del Mar y Ambientales, Universidad de Cádiz, Cádiz, Spain
}

\begin{abstract}
Climatic change-related impacts on coastal areas became an important issue in past decades and nowadays threaten many human settlements and activities. Coastal hazards are linked to flooding and erosion processes associated with sea level rise and the increased strength of hurricanes, cyclones and storms. The main aim of this work is the characterization of coastal storms in Cadiz (SW Spain) and the determination of their recurrence intervals and relationships with several regional cycles. Storm characterization was carried out using the Storm Power Index (Dolan and Davis, 1992) and five classes were obtained, from class I (weak events) to V (extreme events). Storm occurrence probability was $96 \%$ for class I (i.e. almost one event per year) to $3 \%$ for class V. The return period for class $\mathrm{V}$ was 25 years and ranged from 6 to 8 years for classes III and IV storms, e.g. significant and severe events. Classes I and II showed a period of recurrence ranging from 1 to 3 years. Stormy winter seasons were 2009/10 (12 events), 1995/6 and 2002/3 (with 10 events each) and 1993/4 (8 events). Approximately $40 \%$ of the change in monthly wave data and storminess indices was related to several teleconnection patterns, the most important drivers of change being the Arctic Oscillation (AO), 21.45\%, and the North Atlantic Oscillation (NAO), 19.65\%. It is interesting to note that a great number of storms, larger storm duration and higher values of Storm Power Index were only observed when neutral to strong negative NAO and AO phases occurred at the same time ( 89 storms and $3355 \mathrm{~h}$ ) and/or when there was an abrupt change of NAO and AO phases, i.e. they moved from a positive to negative phase without passing through a neutral phase. The results obtained in this work have wider applications for ocean and coastal management. It is suggested that methodology used can be easily applied in different areas where wave buoy data are available. In the same way, information obtained with this kind of work constitutes the first step in the development of coastal protection plans to preserve socio-economic activities from the impact of severe storm events.
\end{abstract}

KEY WORDS Waves; storm; power index; teleconnection patterns; Cadiz; Spain

Received 12 April 2012; Revised 30 July 2012; Accepted 30 July 2012

\section{Introduction}

The recent research on climate change effects on coastal zone has been almost completely devoted to the impacts of sea level rise as a result of the global warming (Komar and Allan, 2008; Phillips and Crisp, 2010). Less attention has been given to the knowledge and trend of wave climate and storms. As suggested by Keim et al. (2004), wave climate, occurrence and distribution of extreme waves and storms are important issues in the occurrence and amount of coastal erosion, the deterioration and (at some places) complete disappearance of ecosystems and the safety of shipping and offshore platforms.

Different researchers around the World have recognized that the height of extreme waves, the number of storms and their intensity have been increasing in last decades (Bacon and Carter, 1991; Allan and Komar, 2000; Dupuis et al., 2006; Komar and Allan, 2008; Soomere, 2008). In a scenario of rising sea levels and

\footnotetext{
* Correspondence to: N. Rangel-Buitrago, Departamento de Ciencias de la Tierra, Facultad de Ciencias del Mar y Ambientales, Universidad de Cádiz, Polígono Río San pedro s/n, 11510 Puerto Real, Cádiz, Spain. E-mail: nelson.rangelbuitrago@mail.uca.es
}

increasing wave heights, the coastline will suffer huge impacts in terms of erosion and flooding especially with respect to low-lying regions that may partly or entirely disappear (Hanson and Larson, 2008).

In order to reduce the impacts of climate change, it is important to provide realistic analyses of the natural variability and trends associated with climatic events, in this case storms. The homogeneity and quality of wave data over long periods (more than 25 years) are essential in any analysis of extreme wave heights, storms and their respective probability of recurrence. Many approaches have been used to document wave climate changes: visual observations, wave buoys data, instrumented ships, satellite altimeters, numerical and physical models (Dupuis et al., 2006; Komar and Allan, 2008).

This work deals with the analysis of a 27 year long wave buoy dataset recorded at Cadiz (SW Spain). The analysis consisted of characterizing winter wave climate, extreme waves and storms characteristics and distribution and their relationships with regional cycles (Teleconnection Patterns) such as the North Atlantic Oscillation (NAO) Index, the East Atlantic (EA) pattern and the Arctic Oscillation (AO), among others. The methodology 
used can be easily applied in different coastal areas around the World where wave buoy data are available for a monitoring period greater than 25 years. Information obtained in this study constitutes a first step in developing coastal response plans to storm impacts for the protection of socio-economic activities, especially tourism. This will be a major concern for coastal managers in future years because storm impacts will be magnified by predicted sea level rise linked to global climate change (Jones and Phillips, 2011).

\subsection{Study area}

This study investigates the wave climate and storm characteristics of an Atlantic Ocean coastal area facing the city of Cadiz, in South-West Spain (Figure 1). The area corresponds with a northwest-southeast oriented coastline which is characterized by a diversity of coastal landforms and environments including sand spits, beaches, dunes, saltmarshes, cliffs and rocky shore platforms.

It has semidiurnal tides and a mesotidal range, with mean values of neap and spring tides of 1.0 and $3.5 \mathrm{~m}$, respectively, and it is affected by western and eastern winds. Western winds are related to Atlantic low pressure systems that can continue for several days and affect large portions of the Iberian Peninsula. They blow from WNW to WSW directions with a mean annual velocity of $16 \mathrm{~km} \mathrm{~h}^{-1}$ and a frequency of $13 \%$. Winds, blowing from $\mathrm{E}$ to $\mathrm{SE}$ directions, with an annual frequency of $20 \%$ and a mean velocity of $28 \mathrm{~km} \mathrm{~h}^{-1}$, are originally formed in the Mediterranean Sea and greatly increase in velocity due to channeling through the Gibraltar Strait. Due to coastline orientation, western winds give rise to both sea and swell waves, while easterly winds have no significant fetch and mainly give rise to sea waves. The main longshore drift flows south-eastward.

During the past 40 years, sea level at the Cadiz coast did not show a single clear trend (Marcos and Tsimplis, 2008; Marcos et al., 2011) and winter storms represent the main coastal hazard in the investigated littoral since they largely affect tourism activities, e.g. the sun, sea and sand (3S) market. They result in major damage to recreational and protection structures causing sand starvation and associated reduction in beach width and scenic value (Anfuso and Gracia, 2005; Meyer-Arendt, 2011).

The area is characterized by extensive sandy beaches that, in the past decade, have undergone erosion with locally recorded values greater than $1 \mathrm{~m}$ year ${ }^{-1}$, essentially associated with the impact of storm events (Muñoz and Enriquez, 1998; Reyes et al., 1999; Benavente et al., 2002; Anfuso et al., 2007; Rangel-Buitrago and Anfuso, 2011a). In order to balance coastal retreat, in the past three decades, more than 600 fills and refills have been
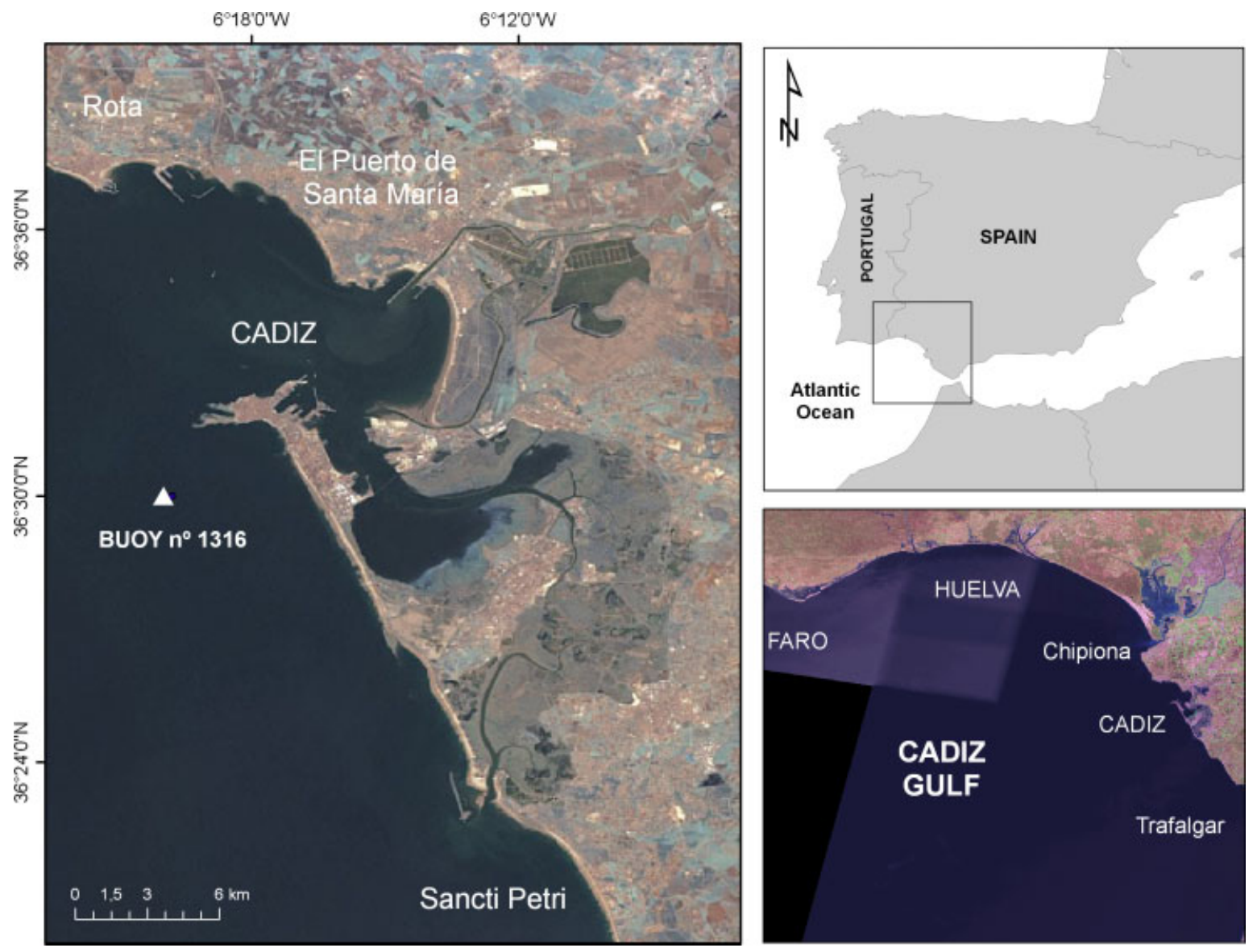

Figure 1. Study area with location of the REDCOS buoy n 1316 operated by Puertos del Estado (Spanish Ministry of Public Works). 
Table I. Characteristics of the five storm classes (modified from Rangel-Buitrago and Anfuso 2011a): range, frequency (number of cases and percentages), mean values $(\mathrm{X})$ of significant wave height and period, storm duration and storm power index per class.

\begin{tabular}{|c|c|c|c|c|c|c|c|}
\hline \multirow[t]{2}{*}{ CLASS } & \multirow[t]{2}{*}{ Range $\left(m^{2} h\right)$} & \multicolumn{2}{|c|}{ Frequency } & \multirow{2}{*}{$\frac{\text { Wave height }}{X(\mathrm{~m})}$} & \multirow{2}{*}{$\frac{\text { Period }}{X(s)}$} & \multirow{2}{*}{$\frac{\text { Duration }}{\mathrm{X}(\mathrm{h})}$} & \multirow{2}{*}{$\frac{\text { Storm power }}{\mathrm{X}\left(\mathrm{m}^{2} \mathrm{~h}\right)}$} \\
\hline & & $N$ & $\%$ & & & & \\
\hline I - Weak & $<515$ & 74 & 57 & 3.46 & 7.02 & 20 & 242.4 \\
\hline II - Moderate & $516-1225$ & 41 & 31 & 4.46 & 7.52 & 40.2 & 785.3 \\
\hline III - Significant & $1226-2537$ & 11 & 8 & 4.56 & 7.5 & 89.6 & 1850 \\
\hline IV - Severe & $2538-5167$ & 2 & 3 & 5.06 & 8.6 & 139.3 & 3311 \\
\hline $\mathrm{V}$ - Extreme & $>5167$ & 1 & 1 & 7.8 & 9.7 & 89 & 5414 \\
\hline
\end{tabular}

performed along the Spanish coast. Investment in beach nourishment during the 1990s along the Atlantic coast of Andalusia was US $\$ 37 \mathrm{M}$, representing the cost of injecting circa $13 \times 10^{6} \mathrm{~m}^{3}$ of sediment (Muñoz et al., 2001).

\section{Methodology}

\subsection{Wave Data}

Real-time wave measurements along the Spanish littoral are available from the coastal buoy network operated by Puertos del Estado (Spanish Ministry of Public Works). Specifically, this work was based on the analysis of data obtained from the scalar buoy $n^{\circ}$ $1316\left(36.50^{\circ} \mathrm{N} ; 6.33^{\circ} \mathrm{W}\right)$, a waverider-datawell instrument which is located at a water deep of $21 \mathrm{~m}$, in front of Cadiz city (Figure 1). Data were logged at $1 \mathrm{~h}$ intervals and included a time series of 163237 wave height and period records acquired between 1983 and 2010. In this study, average annual and monthly winter values of significant wave height $\left(H_{\mathrm{S}}\right)$ and the $99^{\text {th }}$ percentile of $H_{\mathrm{s}}\left(H_{\mathrm{s} 99}\right)$ were used for the characterization of wave climate and definition and description of storms. The $H_{\mathrm{s} 99}$ was used because it is associated with high energy events (Almeida et al., 2011; BACC Author Team, 2008).

According to previous studies carried out by Anfuso et al. (2007) and Rangel-Buitrago and Anfuso (2011a), winter season was defined as the October to March period. The investigated dataset presented a length of 27 years that, according to Komar and Allan (2008), represents a sufficient time period to analyse wave height trend, presence of climate-controlled cycles and wave height annual variations due to climate events.

\subsection{Storm definition and characterization}

Storminess is a key issue in coastal erosion and climate change studies (Li et al., 2011). Coastal engineers normally use the number of storm events or the amount of hours during which a certain wave height threshold is exceed (Goda, 1988; Lemm, et al., 1999; Barr, 2004). Meteorologists use the number of storm systems, characterized by wind speed values grater than a certain threshold or central air pressure values lower than $1000 \mathrm{hPa}$ (Schmith et al., 1998; Zielinski, 2002; Keim et al., 2004). Other researchers use the number of events or the number of hours during which a specific water level threshold is exceed (Eliot and Clarke, 1986; Zhang et al., 2000; Bromirski et al., 2003; Pattiaratchi and Elliot, 2008; Phillips, 2008).

In this work, a storm is defined as a climatic event during which the significant wave height $\left(H_{\mathrm{s}}\right)$ exceeds a threshold over a minimum, specific time, so the following three criteria have to meet:

- Wave height $H_{\mathrm{s}} \geq 2.5 \mathrm{~m}$. This threshold reflects the deep-water wave height at which erosion affected Cadiz beaches (Plomaritis et al., 2009, 2010; RangelBuitrago and Anfuso, 2011a).

- The minimum storm duration was set at $12 \mathrm{~h}$, in this way the storm affected the coast at least during a complete tidal cycle.

- The inter-storm period was set at $1 \mathrm{~d}$ in order to create de-clustered, independent sets of storms (Morton et al., 1997; Dorsch et al., 2008).

The energy content for each storm was calculated according to the Storm Power Index (Dolan and Davis, 1992), which is a valuable indicator of storm strength and associated shoreline erosion (Li et al., 2011), using the formula:

$$
H_{\mathrm{s}}{ }^{2} t_{\mathrm{d}}
$$

Where $H_{\mathrm{s}}$ is the maximum significant wave height in meters and $t_{\mathrm{d}}$ is the storm duration in hours. Once storms were recognized, they were categorized by means of the natural breaks function analysis (Jenks and Caspall, 1971), into five classes from class I (weak) to class V (extreme events, limits presented in Table I).

\subsection{Storm recurrence period}

Frequency analysis was applied to estimate extreme waves and storm power recurrence periods by means of the Generalized Extreme Value (GEV) distribution; it is a family of continuous probability distributions developed within extreme value theory to combine the Gumbel, Fréchet and Weibull families also known as types I, II and III extreme value distributions (Coles, 2001). The GEV distribution was calculated according to:

$$
F(x)=\exp \{-\exp [-(x-u) / \alpha] 1 / k\}
$$


Where $x$ is the random variable and $u, \alpha$ and $k$ are location, scale and shape parameters, respectively, that should be estimated for each sample. The equation reduces to type I (or Gumbel, for $k=0$ ), type III (or Weibull, for $k>0$ ) or type II (for $k<0$ ) distribution. The equation for the type I (Gumbel) distribution is:

$$
F(x)=\exp \{-\exp [-(x-u) / \alpha]\}
$$

The methods of parameter estimation for each distribution are also discussed in detail in Rao and Hamed (2000). In this study, the method of moments and maximum likelihood was applied to estimate the distribution of investigated parameters. The root mean square error was then used to select the appropriate distribution. To investigate the recurrence period, wave and storm data were plotted with the Gringorten (1963) plotting position formula and the Gumbel distribution was fitted to the data. The distribution function is given by the formula:

$$
\mathrm{TR}=N+0.12 / \mathrm{m}-0.44
$$

Where $N$ is the number of annual maximum observations and $m$ is the rank of extreme waves or storm power values from the lowest to the highest observation. According to the Gumbel distribution, the expected significant values for a selected return period can be estimated as follows (reduced value):

$$
\mathrm{TRp}=-\ln [-\ln (1-1 / \mathrm{TR})]
$$

\subsection{Northern Hemisphere teleconnection patterns}

The term Regional Cycle and Teleconnection Pattern are terms referred to a recurring and persistent, large scale pattern of pressure and circulation anomalies that span vast geographical areas (Hatzaki et al., 2006). Teleconnection patterns are also referred to as preferred modes of low-frequency (or long time scale) variability of the atmospheric circulation with geographically fixed centres of action.

The NOAA Climate Dynamics Research Centre has shown the existence of several teleconnection patterns influencing the European region (including the area investigated in this study):

- North Atlantic Oscillation - NAO (Wallace and Gutzler, 1981; Hurrel, 1995; Barnston and Livezey, 1987).

- East Atlantic Pattern - EA (Esbensen, 1984; Wallace and Gutzler, 1981).

- East Atlantic/Western Russia - EA/WR (Barnston and Livezey, 1987)

- Scandinavia - SCAND (Barnston and Livezey, 1987).

- Polar/Eurasia - POL (Barnston and Livezey, 1987).

- East Pacific - North Pacific Pattern - EP-NP (Bell and Janowiak, 1995).

- Pacific/North American Pattern - PNA (Barnston and Livezey, 1987; Chen and van den Doo, 2003).

- Arctic Oscillation - AO (Zhou et al., 2001; Higgins et al., 2002).
Previous teleconnection patterns were recognized as the most important characterizing parameters of the European climate system, the NAO apparently being the most important. A link between these teleconnection patterns and seasonal, interannual and decadal variations in weather, waves and storminess for the European Atlantic coastlines was established by different authors (Wang et al., 2008; Lozano et al., 2004; Hurrel and Deser, 2009; Dodet et al., 2010). Likewise, changes in coastal evolution during the second half of the 20th century were also connected to modulations of the NAO Index (Lozano et al., 2004; Esteves et al., 2011; Thomas et al., 2011; O'Connor et al., 2011).

In this study, distributions of average winter monthly and annual values of NAO, EA, EATL/WRUS, SCAND, Polar/Eurasia, EP-NP, PNA and AO from 1983 to 2010 were compared with winter wave height data and storm classes by means of multiple and independent regression analysis.

\section{Results}

\subsection{Wave climate}

Data showed a clear pattern of cyclic variations of average monthly values of significant wave height $\left(H_{\mathrm{s}}\right)$ and $99^{\text {th }}$ percentile of $H_{\mathrm{s}}\left(H_{\mathrm{s} 99}-\right.$ Figure 2$)$. Waves were usually low $\left(H_{\mathrm{s}}<0.8 \mathrm{~m}, H_{\mathrm{s} 99}<1.8 \mathrm{~m}\right)$ in May to August period (late spring to summer), reaching minimum values in August $\left(H_{\mathrm{s}}=0.6 \mathrm{~m}, H_{\mathrm{s} 99}=1.22 \mathrm{~m}\right)$. During the winter season, waves rapidly increased in height, reaching peak values $\left(H_{\mathrm{s}}=1.2 \mathrm{~m}\right.$ and $\left.H_{\mathrm{s} 99}=3.1\right)$ in December to January period.

Trends of average monthly and annual values of $H_{\mathrm{s}}$ and $H_{599}$ during the investigated period (1983-2010) and associated linear regression analyses, were plotted in Figure 2; data showed a small decrease in monthly (Avg: $1 ; r^{2}: 0.018 ; P: 0.118$; trend: -0.0011 ) and annual (Avg: $1 ; r^{2}: 0.085 ; P: 0.14$; trend: -0.008$) H_{\mathrm{s}}$ values, whereas $H_{\mathrm{s} 99}$ remained constant. However, low recorded values of Pearson coefficient revealed that these trends are not statistically significant $(P$ monthly: $0.118 ; P$ annual: 0.14). Similar results were obtained using the Mann-Kendall trend test and the Wilcoxon rank-sum test commonly used in such kind of studies (Carter and Draper, 1988; Bacon and Carter, 1991; Allan and Komar, 2000).

Considering the 27 investigated winters, a great variability of average monthly wave height was observed. Low $H_{\mathrm{s}}$ values $(<0.8 \mathrm{~m})$ were recorded in winter seasons within the 1990/1-1994/5, 1998/9-2001/2 and 2004/5-2007/8 periods; high $H_{\mathrm{s}}$ values $(\approx 1.3 \mathrm{~m})$ were recorded during the 1995/6, 1996/7, 1997/8, 2002/3, 2003/4 and 2009/10 winter season periods. Concerning extreme wave conditions, the highest monthly value was $7.8 \mathrm{~m}$ (recorded December 1989) and the average value of extreme wave height was $4.6 \mathrm{~m}$.

Figure 2 evidenced a quasi-periodic 3-4 year behaviour in the recurrence of high wave height values. A 


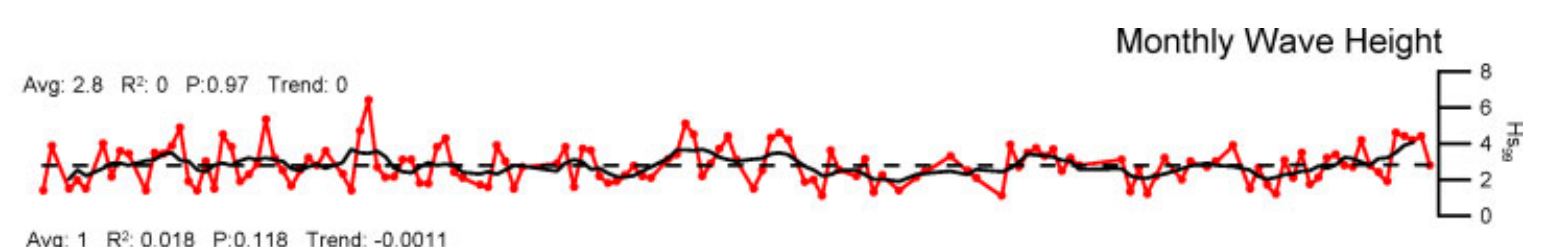

$\begin{array}{lll}\text { Avg: } 1 R^{2}: 0.018 & \text { P:0.118 Trend }-0.0011\end{array}$
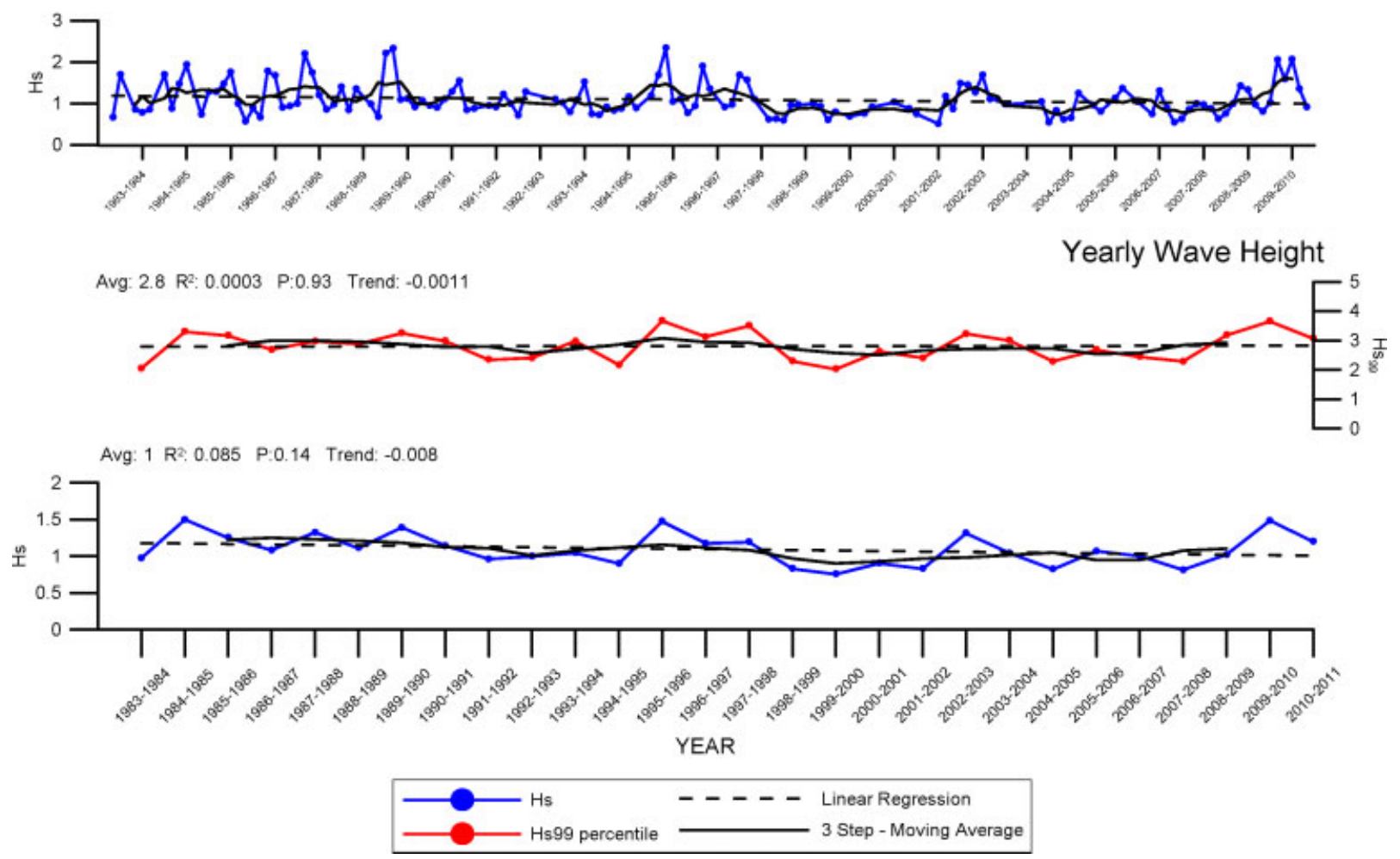

Figure 2. Winter monthly and annual $H_{\mathrm{s}}$ and $H_{\mathrm{s} 99}$ for the 1983-2009 period.

spectral analysis of time series of extreme waves, based on the Fourier transformation (Boashash, 2003), indicated a cyclic trend of 3 years. The probability density function for the period of recurrence and occurrence probability of maximum annual $H_{\mathrm{s}}$ was obtained (Figure 3) applying the GEV proposed by Jenkinson (1955). The probability of occurrence of 3.0-3.5 m waves ranged from the 86 to $96 \%$, meanwhile the probability of occurrence of waves higher than $6 \mathrm{~m}$ did not reach $6 \%$. The recurrence periods for 4 and $8 \mathrm{~m}$ waves were 5 and 50 years respectively.

\subsection{Storm characteristics and trend}

One hundred and nineteen storms were recorded during the investigated 27 year time span. Classes I (weak) and II (moderate) accounted for 55 and 33\%, respectively, of records. These values were very close to those obtained by Dolan and Davis (1992), Moritz and Moritz (2006), Mendoza and Jimenez (2008) and Rangel-Buitrago and Anfuso (2011a) in United States and Spain. Class III (significant), constituted $8 \%$ of the records and classes IV (severe) and V (extreme) accounted for 3 and 1\%, respectively (Table I).

Associated average wave height and storm duration values presented important variations (Table I) and average wave period ranged from 7.0 (class I) to $9.7 \mathrm{~s}$ (class V). Storm power values were larger than the ones proposed by Dolan and Davis (1992) because of the major threshold of storm wave height selected, and apparent longer duration of investigated storms. Dealing with monthly distribution, classes I and II events were observed over the entire winter season, class III from November to March and classes IV and V only in December and January, January being the stormiest month.

The distribution of the most commonly used storminess indices over the 27 years is shown in Figure 4. Considering the number of storms per year (Figure 4), stormy winter seasons were 2009/10 (12 events), 1995/6 and 2002/3 (with 10 events each) and 1993/4 (8 events); no storms at all were recorded during 1994/5. Despite some anomalous peaks, the 1983/4-1986/7, 1990/1-1992/3, 1998/9-2001/2 and 2003/4-2008/9 winter periods presented the lowest average number of storms (Figure 4); the 3 year moving average did not show a clear trend in storm occurrence whereas indicated a 6-7 years cyclic behaviour with storm peaks observed in 1989/90, 1995/6, 2002/3 and 2009/10 winter seasons.

Patterns of variability of storms duration and Storm Power Index were very similar to that found for the number of storms (Figure 4). This was because, in general, stormy winter seasons presented a great number 

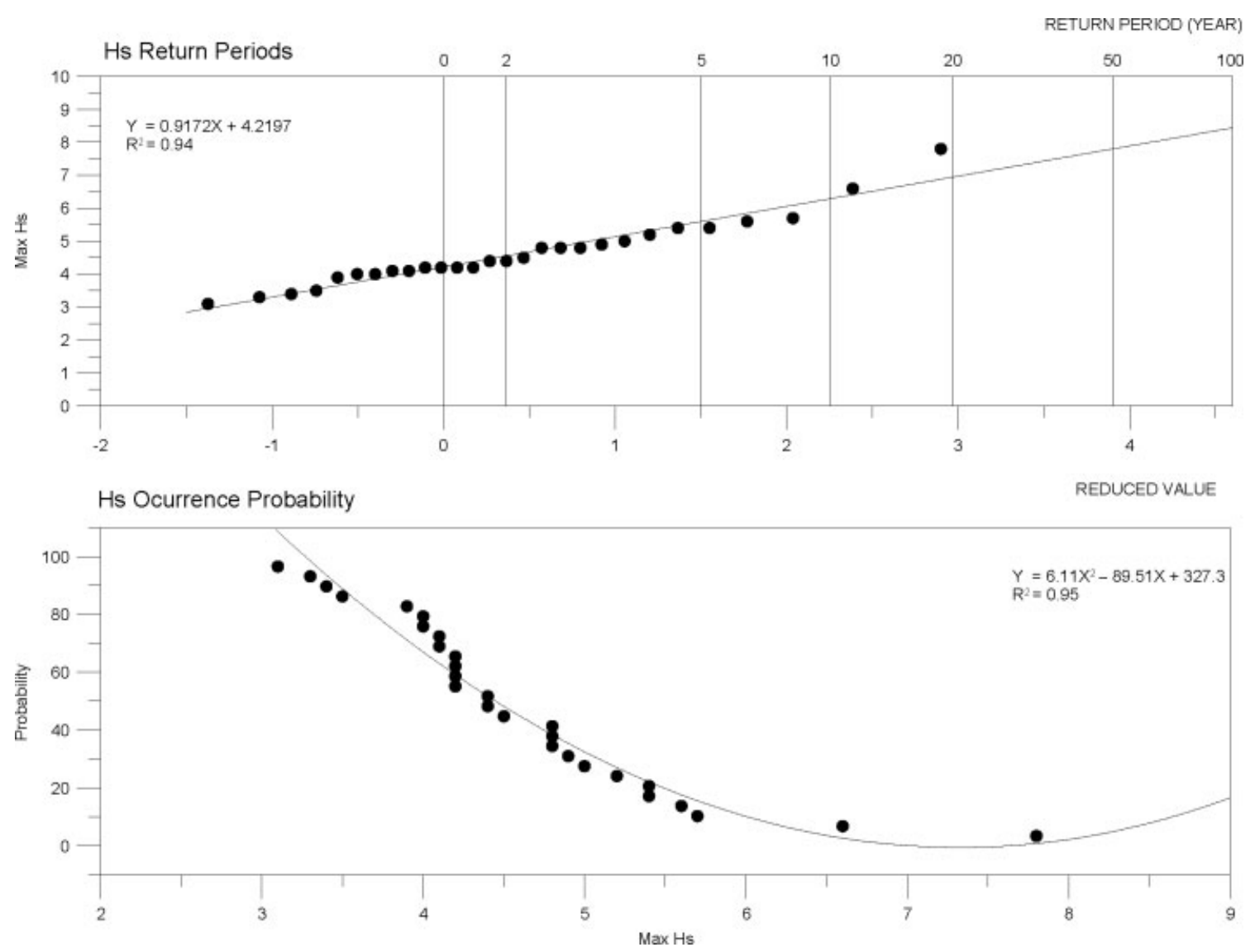

Figure 3. Wave Recurrence and probability. Annual maximum wave height plotted versus the reduced value from the Gumbel distribution using the Gringoten Plotting position and wave occurrence probability plotted versus the annual maximum wave height value.

of storms which gave many hours under storm conditions and therefore an elevated storm power.

Linear regressions analysis, Mann-Kendall trend tests and Wilcoxon rank-sum tests did not show a clear trend of storminess indices (i.e. number of storms: Avg: $4.85 ; r^{2}: 0.040$; trend: 0.082 ) although they indicated a 6-7 year period (return periods: $r^{2}: 0.97$ and occurrence probability: $r^{2}$ : 0.95 - Figures 4 and 5). In order to further investigate storm periodicity, the return period and occurrence probability of each storm class were estimated using the method of the maximum likelihood based on the Gumbel distribution of annual maximum storm power values. The probability plot for each storm power value was represented in Figure 5 and derived using the Gringoten (1963) plotting position analysis suggested by Cook (2004) and Goel et al. (2004).

\section{Discussion}

\subsection{Wave climate and storm trend}

Results obtained confirmed the clear seasonal nature of wave height in Cadiz area as previously observed by Menéndez et al. (2004), Anfuso and Gracia (2005) and Rangel-Buitrago and Anfuso (2011a).

The time series of average and extreme monthly values of wave height presented similar behaviour. The lack of a clear trend of both features disappointed with observations carried out by several authors who suggested an increase in mean significant wave height in many Oceans around the World and, more closely, on the Northern part of the North Atlantic Ocean. Nevertheless, results obtained confirmed observations carried out at the mid and southern latitudes of the North Atlantic Ocean, by Dolan et al. (1989) and WASA (1998), and at regional scale, e.g. Cadiz Gulf, by Menéndez et al. (2004), Ferreira et al. (2009) and Almeida et al. (2011).

Concerning the distribution of stormy years, it was quite close to the one presented at local and regional scales by previously mentioned authors. Specifically, Rodriguez et al. (2003) used wind records and individuated eight stormy years in Huelva during the 1962-1999 period; two out of three of the recorded storminess seasons after 1983 (e.g. 1989/90 and 1995/6) corresponded with the two years that recorded the highest values of Storm Power Index.

Almeida et al. (2011) used HIPOCAS and offshore wave buoy data recorded in Faro, in the Algarve coast (Southern Portugal), and affirmed that the storminess years were 1987, 1989, 1995, 1996, 1997, 2002, 2003 and 2009. All these except one, i.e. 2003, confirmed this study's observations since they corresponded with years characterized by high Storm Power Index values, a great number of storms and high values of storm duration (Figure 4). Similarities to previous studies indicate a general homogeneity of wave climate in the Cadiz Gulf. It 
(a)

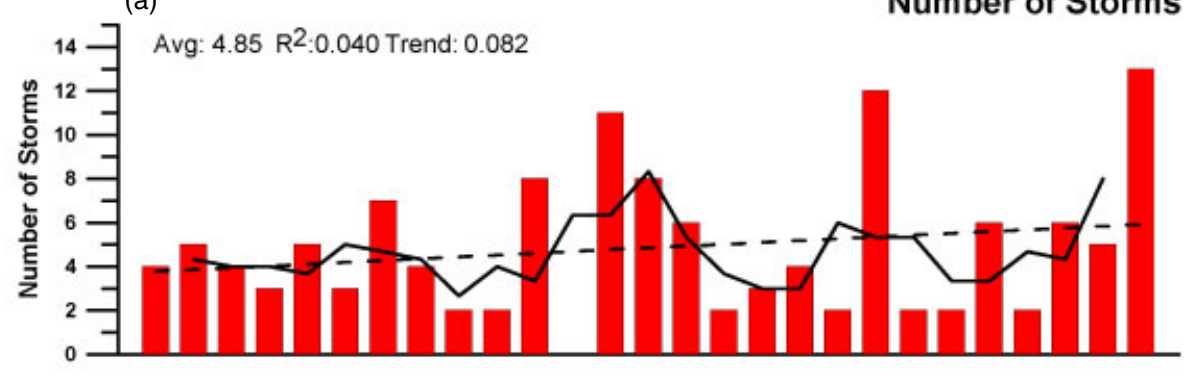

(b)

Storm Durations

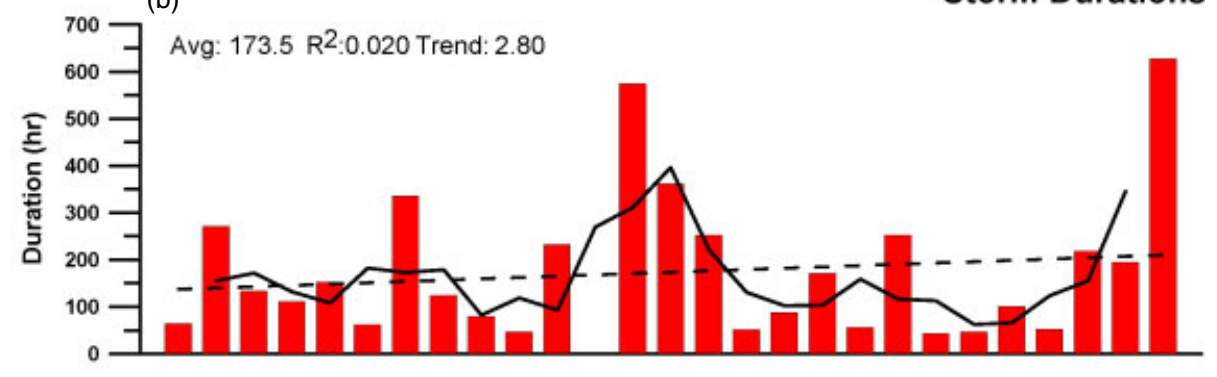

(c)

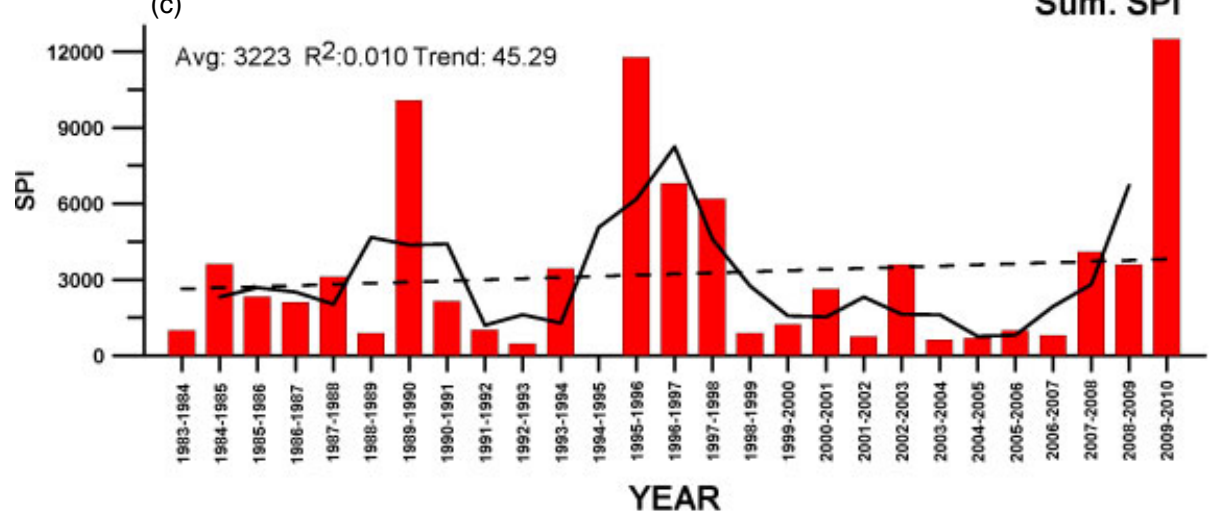

\begin{tabular}{ll|}
----- & Linear Regression \\
\hline & 3 Step- Moving Average \\
\hline
\end{tabular}

Figure 4. Distribution of the number of storms, duration and sum of storm power per winter year with their respective linear regression and the 3 year moving average. Average values (Avg), Root mean square $\left(r^{2}\right)$ and trends also presented.

is broadly exposed to storms approaching from the third and fourth quadrants, as observed by Rangel-Buitrago and Anfuso (2011b), who analysed HIPOCAS datasets at five locations along Andalusia's Atlantic littoral.

Comparing obtained data in this study with observations carried out in Northern Europe, a certain correspondence was evidenced with data presented by O'Connor et al. (2011). They analysed gale-day frequency in Northern Ireland finding a peak in storm generation in the early 1990s, before an apparently decreasing until 2009. The most energetic conditions recorded in this work (1995/6, 1996/7, 2002/3 and 2009/10) matched the extreme weather conditions recorded over the same periods in Wales (Phillips, 2008; Phillips and Crisp, 2010; Thomas et al., 2011), Lithuania (Dailidiene et al., 2011; Kelpsaite et al., 2011), Estonia and Southern Gulf of Finland (Suursaar, 2010). These authors reported significant changes in wind direction, high wind speeds, mildest temperature records and an increase in damage to coastal structures (because of storm impacts). In addition, fair weather conditions recorded in Cadiz area during 1998 were similar to the observations carried out in England and reported by Environmental Scientist (2000) that observed as 1998 and the 1990s respectively were the third warmest year and the warmest decade on records in the UK.

Concerning storm occurrence probability in the investigated area, it was $96 \%$ for class I (i.e. almost one event per year) to $3 \%$ for class $\mathrm{V}$. The return period for class $\mathrm{V}$ was 25 years and ranged from 6 to 8 years for classes III and IV storms, e.g. significant and severe events (return periods: $r^{2}: 0.97$ and occurrence probability: $r^{2}: 0.95-$ Figure 5 ). Such periodicity was similar to the 6-7 year periodicity proposed for Cadiz and Huelva respectively by Muñoz and Enriquez (1998) and Rodriguez et al. (2003) and to the 7-8 year periodicity recorded by Ferreira et al. (2009) and Almeida et al. (2011) in Faro (Southern Portugal) and in the southern part of North Atlantic by WASA (1998) and Matulla et al. (2007). 

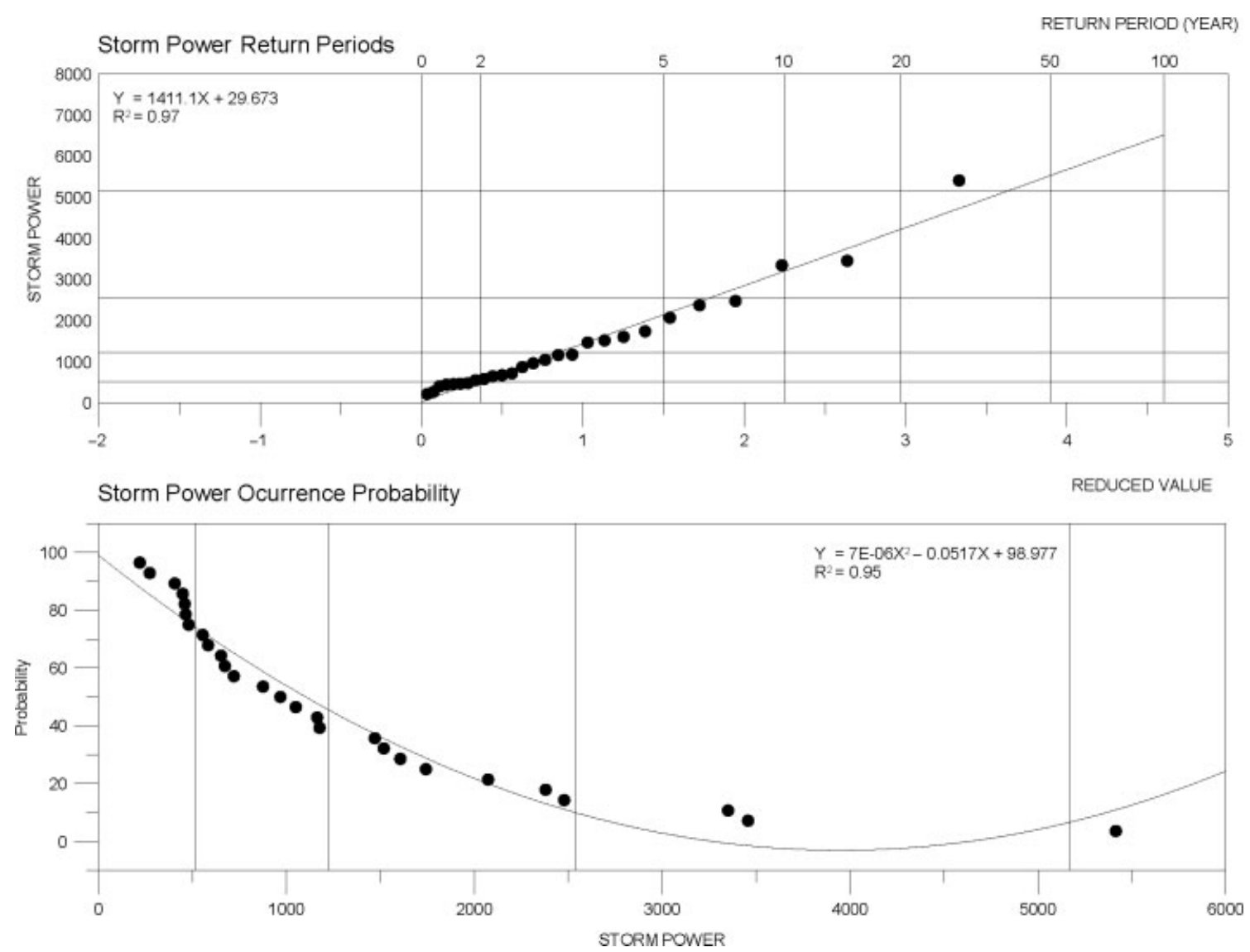

Figure 5. Storm recurrence and probability for the different storm classes in Cadiz littoral. Annual maximum storm power plotted versus the reduced value from the Gumbel distribution using the Gringoten plotting position and storm occurrence probability plotted versus the annual maximum storm power.

Lastly, classes I and II showed a period of recurrence ranging from 1 to 3 years, similar to the $2-3$ year recurrence period for minor storm events detected in Cadiz and Huelva respectively by Muñoz and Enriquez (1998) and Rodriguez et al. (2003).

\subsection{Storms and Northern Hemisphere teleconnection patterns}

A series of linear regression analyses and Pearson correlation tests were performed considering the annual and monthly wave data $\left(H_{\mathrm{s}}\right.$ and $\left.H_{\mathrm{s} 99}\right)$, storminess indices and teleconnection patterns. The analysis of annual and monthly datasets gave very different result, the latter presenting clearer trends (Table II).

Multiple linear regression analysis between wave data, storminess indices and the teleconnection patterns indicated that approximately $40 \%$ of the change in monthly wave data and all used storminess indices related to changes in the eight teleconnection patterns used in this work. Drivers of change being the AO, with $21.45 \%$, and NAO, with the $19.65 \%$ (Table II); both being important controllers on short- and long-term climatic variability in North Atlantic Ocean, Europe and the Mediterranean basin (Türkeş and Erlat, 2008).

Specifically, the AO is an atmospheric circulation pattern reflecting the non-seasonal sea level pressure variations north of $20^{\circ} \mathrm{N}$ latitude and varies over time with no particular periodicity; it is characterized by pressure anomalies of opposite sign, one located in the Arctic and the other centred at $37-45^{\circ} \mathrm{N}$ latitude (Thompson and Wallace, 1998). The AO is believed to be causally related to, and thus partially predictive of, weather patterns in locations many thousands of miles away, including many major population centres of Europe and North America.

In the same way, negative $\mathrm{AO}$ values play an important role in determining extreme conditions such as frozen precipitations, strong winds and extreme weather events in general over the Northern Hemisphere and in particular over the North Eastern United States, the Mediterranean area and China (Thompson and Wallace, 2000; Higgins et al., 2002; Wettstein and Mearns, 2002; Xoplaki, 2002; Türkeş and Erlat, 2008; Mao et al., 2011).

The NAO is defined as the difference in normalized sea level pressure computed between a station in the Azores (Ponta Delgada) or Southern Europe (e.g., Gibraltar, Lisbon) and another station in Iceland (Stykkisholmur). Negative NAO values give rise to changes in the surface westerly winds across the North Atlantic that eventually affects The Azores and the western European coasts (Andrade et al., 2008). In this respect, severity of winters in northern and western Europe (WMO, 1995; Esteves et al., 2011; Thomas et al., 2011), temperature anomalies (Hurrell, 1995; Trigo et al., 2002), intensity 
a) Annual data correlations

Table II. Pearson correlation values for winter annual (a) and monthly (b) data.

\begin{tabular}{|c|c|c|c|c|c|c|c|c|c|c|}
\hline $\begin{array}{l}\text { Teleconnection } \\
\text { pattern }\end{array}$ & & $\begin{array}{c}\mathrm{H}_{\mathrm{s}} \\
\text { mean } \\
\text { monthly }\end{array}$ & $\begin{array}{c}\mathrm{H}_{\mathrm{s} 99} \\
\text { percentile }\end{array}$ & $\begin{array}{c}\text { Number } \\
\text { of } \\
\text { storms }\end{array}$ & $\begin{array}{c}\text { Duration } \\
\text { of } \\
\text { storms }\end{array}$ & $\begin{array}{c}\text { Avg } \\
\text { duration }\end{array}$ & $\begin{array}{c}\text { Max } \\
\text { duration }\end{array}$ & $\begin{array}{l}\text { Sum } \\
\text { SPI }\end{array}$ & $\begin{array}{l}\text { Avg } \\
\text { SPI }\end{array}$ & $\begin{array}{l}\text { Max } \\
\text { SPI }\end{array}$ \\
\hline North Atlantic & Correlation & -0.48 & -0.59 & -0.51 & -0.50 & -0.33 & -0.52 & -0.42 & -0.25 & -0.23 \\
\hline Oscillation & $P$-value & 0.01 & 0.00 & 0.01 & 0.01 & 0.09 & 0.01 & 0.03 & 0.21 & 0.25 \\
\hline$(\mathrm{NAO})$ & $r^{2}$ & 0.23 & 0.35 & 0.26 & 0.25 & 0.11 & 0.27 & 0.17 & 0.06 & 0.05 \\
\hline East Atlantic & Correlation & 0.33 & 0.34 & 0.32 & 0.31 & 0.25 & 0.24 & 0.32 & 0.31 & 0.30 \\
\hline \multirow{2}{*}{ (EA) } & $P$-value & 0.09 & 0.08 & 0.11 & 0.11 & 0.20 & 0.22 & 0.10 & 0.12 & 0.13 \\
\hline & $r^{2}$ & 0.11 & 0.12 & 0.10 & 0.10 & 0.06 & 0.06 & 0.10 & 0.10 & 0.09 \\
\hline East & Correlation & 0.13 & 0.10 & -0.13 & -0.15 & -0.11 & -0.20 & -0.11 & -0.08 & -0.11 \\
\hline Atlantic/Western & $P$-value & 0.52 & 0.62 & 0.53 & 0.47 & 0.59 & 0.33 & 0.59 & 0.70 & 0.59 \\
\hline Russia (EA/WR) & $r^{2}$ & 0.02 & 0.01 & 0.02 & 0.02 & 0.01 & 0.04 & 0.01 & 0.01 & 0.01 \\
\hline Scandinavia & Correlation & 0.45 & 0.48 & 0.41 & 0.38 & 0.35 & 0.44 & 0.23 & 0.13 & 0.06 \\
\hline \multirow[t]{2}{*}{ (SCAND) } & $P$-value & 0.02 & 0.01 & 0.03 & 0.05 & 0.07 & 0.02 & 0.26 & 0.53 & 0.78 \\
\hline & $r^{2}$ & 0.21 & 0.23 & 0.17 & 0.14 & 0.13 & 0.20 & 0.05 & 0.02 & 0.00 \\
\hline Polar/Eurasia & Correlation & 0.11 & 0.06 & -0.08 & -0.10 & -0.09 & -0.06 & -0.07 & -0.07 & -0.09 \\
\hline Pattern & $P$ value & 0.58 & 0.76 & 0.70 & 0.63 & 0.67 & 0.78 & 0.72 & 0.72 & 0.64 \\
\hline (POL) & $r^{2}$ & 0.01 & 0.00 & 0.01 & 0.01 & 0.01 & 0.00 & 0.01 & 0.01 & 0.01 \\
\hline Arctic & Correlation & -0.43 & -0.47 & -0.52 & -0.51 & -0.34 & -0.46 & -0.39 & -0.22 & -0.16 \\
\hline Oscillation & $P$-value & 0.03 & 0.01 & 0.01 & 0.01 & 0.09 & 0.02 & 0.04 & 0.26 & 0.42 \\
\hline$(\mathrm{AO})$ & $r^{2}$ & 0.18 & 0.22 & 0.27 & 0.26 & 0.11 & 0.21 & 0.15 & 0.05 & 0.03 \\
\hline Pacific/North & Correlation & -0.09 & -0.13 & 0.11 & -0.03 & -0.16 & -0.12 & -0.06 & -0.14 & -0.19 \\
\hline American & $P$-value & 0.67 & 0.52 & 0.57 & 0.89 & 0.44 & 0.54 & 0.77 & 0.48 & 0.33 \\
\hline Pattern (PNA) & $r^{2}$ & 0.01 & 0.02 & 0.01 & 0.00 & 0.02 & 0.01 & 0.00 & 0.02 & 0.04 \\
\hline East Pacific/ & Correlation & -0.07 & -0.12 & 0.11 & -0.03 & -0.16 & -0.12 & -0.07 & -0.16 & -0.22 \\
\hline North Pacific & $P$-value & 0.72 & 0.56 & 0.60 & 0.88 & 0.42 & 0.55 & 0.72 & 0.43 & 0.28 \\
\hline Pattern (EP/NP) & $r^{2}$ & 0.01 & 0.01 & 0.01 & 0.00 & 0.03 & 0.01 & 0.01 & 0.03 & 0.05 \\
\hline \multicolumn{11}{|c|}{ b) Monthly data correlations } \\
\hline North Atlantic & Correlation & -0.43 & -0.46 & -0.49 & -0.40 & -0.36 & -0.38 & -0.35 & -0.33 & -0.33 \\
\hline Oscillation & $P$-value & $<0.0001$ & $<0.0001$ & $<0.0001$ & $<0.0001$ & $<0.0001$ & $<0.0001$ & $<0.0001$ & $<0.0001$ & $<0.0001$ \\
\hline (NAO) & $r^{2}$ & 0.18 & 0.22 & 0.24 & 0.16 & 0.13 & 0.14 & 0.12 & 0.11 & 0.11 \\
\hline East & Correlation & 0.14 & 0.07 & 0.06 & 0.08 & 0.13 & 0.11 & 0.09 & 0.17 & 0.16 \\
\hline Atlantic & $P$-value & 0.11 & 0.42 & 0.49 & 0.35 & 0.13 & 0.21 & 0.29 & 0.06 & 0.07 \\
\hline (EA) & $r^{2}$ & 0.02 & 0.00 & 0.00 & 0.01 & 0.02 & 0.01 & 0.01 & 0.03 & 0.02 \\
\hline East Atlantic/ & Correlation & 0.16 & 0.07 & 0.07 & -0.01 & 0.00 & 0.01 & -0.02 & 0.00 & 0.00 \\
\hline Western Russia & $P$-value & 0.06 & 0.44 & 0.41 & 0.94 & 0.96 & 0.91 & 0.82 & 0.99 & 0.96 \\
\hline (EA/WR) & $r^{2}$ & 0.03 & 0.00 & 0.01 & 0.00 & 0.00 & 0.00 & 0.00 & 0.00 & 0.00 \\
\hline Scandinavia & Correlation & 0.22 & 0.20 & 0.18 & 0.21 & 0.17 & 0.22 & 0.17 & 0.17 & 0.12 \\
\hline \multirow[t]{2}{*}{ (SCAND) } & $P$-value & 0.01 & 0.02 & 0.03 & 0.02 & 0.05 & 0.01 & 0.04 & 0.04 & 0.18 \\
\hline & $r^{2}$ & 0.05 & 0.04 & 0.03 & 0.04 & 0.03 & 0.05 & 0.03 & 0.03 & 0.01 \\
\hline Polar/Eurasia & Correlation & 0.00 & 0.03 & -0.04 & -0.07 & -0.06 & -0.03 & -0.05 & -0.02 & -0.03 \\
\hline Pattern & $P$-value & 0.96 & 0.73 & 0.68 & 0.42 & 0.50 & 0.70 & 0.53 & 0.81 & 0.76 \\
\hline (POL) & $r^{2}$ & 0.00 & 0.00 & 0.00 & 0.00 & 0.00 & 0.00 & 0.00 & 0.00 & 0.00 \\
\hline Arctic & Correlation & -0.47 & -0.43 & -0.51 & -0.48 & -0.43 & -0.44 & -0.40 & -0.39 & -0.37 \\
\hline Oscillation & $P$-value & $<0.0001$ & $<0.0001$ & $<0.0001$ & $<0.0001$ & $<0.0001$ & $<0.0001$ & $<0.0001$ & $<0.0001$ & $<0.0001$ \\
\hline$(\mathrm{AO})$ & $r^{2}$ & 0.22 & 0.19 & 0.26 & 0.23 & 0.18 & 0.20 & 0.16 & 0.15 & 0.14 \\
\hline Pacific/North & Correlation & 0.07 & 0.04 & 0.11 & 0.05 & 0.01 & 0.02 & 0.05 & 0.05 & 0.07 \\
\hline American & $P$-value & 0.40 & 0.63 & 0.23 & 0.58 & 0.94 & 0.81 & 0.57 & 0.59 & 0.41 \\
\hline Pattern (PNA) & $r^{2}$ & 0.01 & 0.00 & 0.01 & 0.00 & 0.00 & 0.00 & 0.00 & 0.00 & 0.01 \\
\hline East Pacific/ & Correlation & 0.00 & 0.00 & 0.06 & -0.01 & -0.05 & -0.03 & 0.00 & 0.00 & 0.03 \\
\hline North Pacific & $P$-value & 0.98 & 0.98 & 0.46 & 0.95 & 0.60 & 0.70 & 0.98 & 0.96 & 0.76 \\
\hline Pattern (EP/NP) & $r^{2}$ & 0.00 & 0.00 & 0.00 & 0.00 & 0.00 & 0.00 & 0.00 & 0.00 & 0.00 \\
\hline
\end{tabular}

In bold significant correlation values.

and frequency of winter daily precipitation and storms over the Iberian Peninsula (Muñoz-Díaz and Rodrigo (2003); Gallego et al., 2005; Almeida et al., 2011) are partially influenced by this teleconnection pattern.
The relative importance of the NAO index in the development of extreme events in the Northern Hemisphere was confirmed in this study and it was in agreement with several authors such as: Matulla et al. (2007) that 

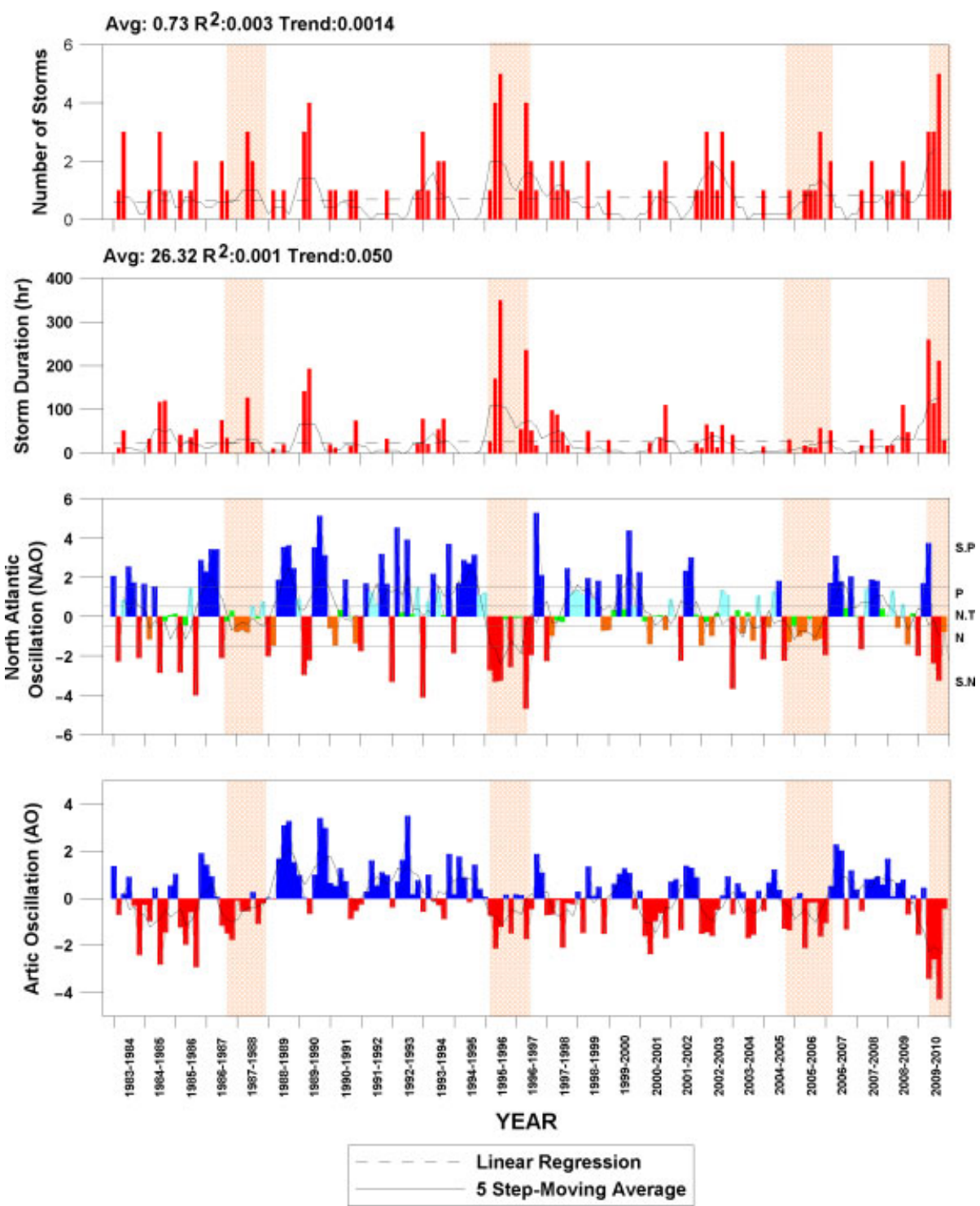

Figure 6. Monthly values of number of storms, storm durations, North Atlantic Oscillation (NAO) and Arctic Oscillation (AO). The dashed polygons highlight 'stormy' years. NAO phases: SN, strong negative; N, negative; NT, neutral; P, positive; SP, strong positive.

showed as the NAO index was not particularly helpful in the determination of storm conditions in central Europe and Andrade et al. (2008) that explained the "partial responsibility' of the NAO index over storminess and their temporal distribution over the Azores region from 1865 to 2009. Previous assumptions are in accordance with the observations of Allan et al. (2009), which found a poor correlation between the 'Gibraltar - SW Iceland NAO' and the distribution of severe winter storms over the British Isles and Almeida et al. (2011), which indicated that NAO index variations were not exclusively responsible of winter wave and storm distribution along the South coast of Portugal.

Considering that the $\mathrm{AO}$ and the NAO were the principal teleconnection patterns involved in changes of storminess patterns over the study area (Table II), their relationships with number and duration of storms and five step moving average were investigated (Figure 6). In order to facilitate the analysis, NAO data were divided in five phases (strong negative, negative, neutral, positive and strong positive) according to Pinto et al. (2009) and Donat et al. (2010). Negative phases of NAO and AO presented a certain level of correlation with the different storminess indices, and as an example the number $(C$ : $\left.-0.49, r^{2}: 0.24\right)$ and duration of storms (C: -0.40 , $\left.r^{2}: 0.16\right)$ were presented in Figure 6 and Table II. It is interesting to remark that a great number of storms, larger storm durations and higher values of Storm Power Index were only observed when neutral to strong negative NAO and $\mathrm{AO}$ phases occurred at the same time (89 storms and $3355 \mathrm{~h}$ - Figure 6) and/or when occurred an abrupt change of NAO and AO phases, i.e. they moved from a positive phase to a negative phase without passing through a neutral phase. The behaviour of NAO and AO indexes was described by Thompson and Wallace (1998) who observed as the AO resembles the NAO in numerous respects. However, the AO's primary centre of action covers more of the Arctic, giving it a more 

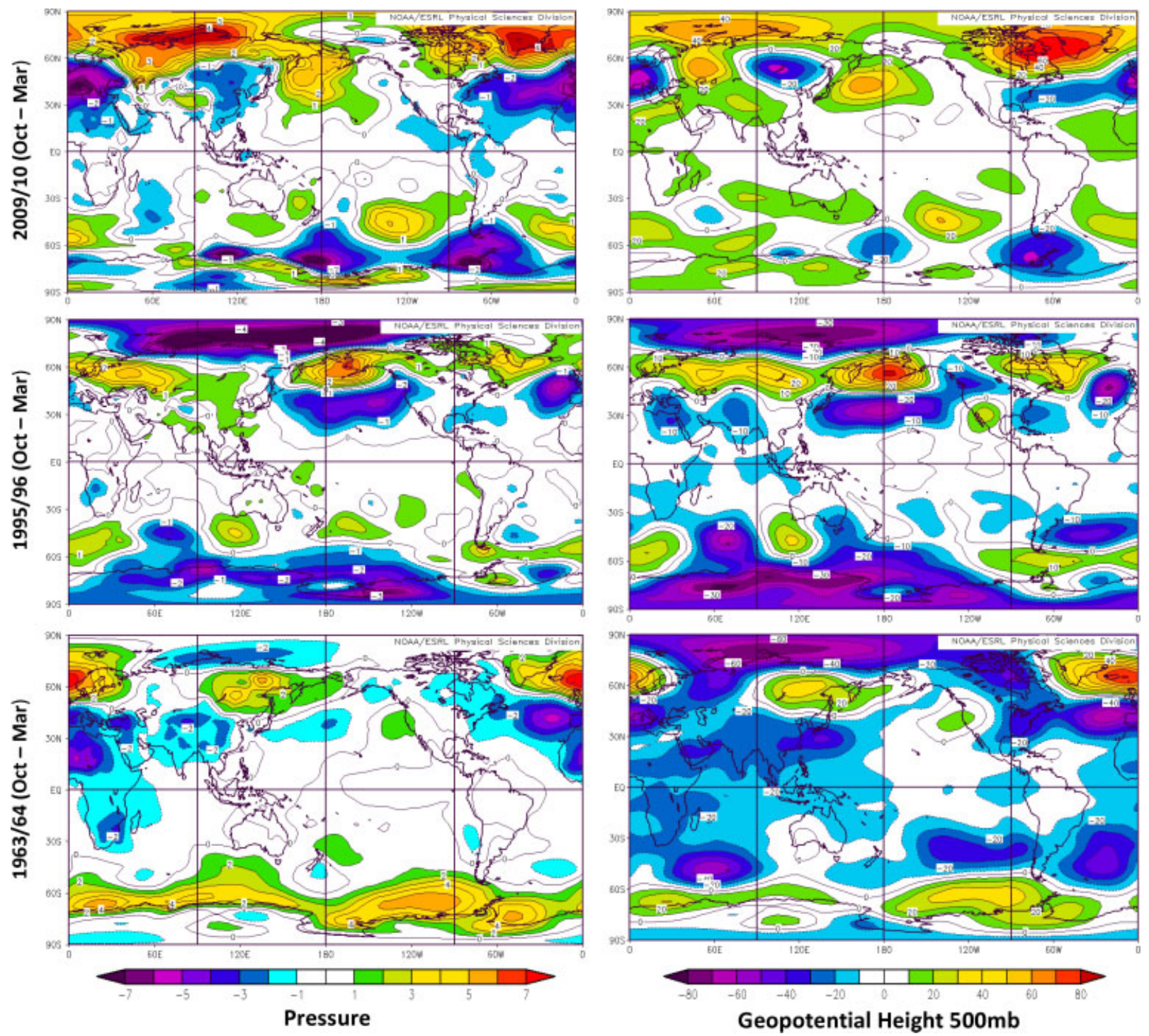

Figure 7. Pressure and Geopotential height anomalies at $500 \mathrm{mb}$ over the 2009/10, 1995/96 and 1963/64 winter seasons (from NCEP-NCAR reanalysis). Great storminess and extremely coldest conditions were recorded during the aforementioned winter seasons.

zonal symmetrical appearance. Hence, although the AO and the NAO patterns resemble each other, there is a clear distinction that could play a guiding role in determining the physical mechanisms that control the variability of the Northern Hemisphere climate (Wallace, 2000). Rogers and McHugh (2002) examined whether the NAO and the AO were inseparable spatial modes of atmospheric circulation in the Northern Hemisphere: the analysis of the spring, summer and autumn sea level pressure fields revealed that the NAO and the AO-liken patterns occurred as separate regional teleconnections forming the first and second principal components, respectively.

Specifically, in the investigated area, 1995/1996 was one of the most storminess years over past decades (Figure 6) and the great number of recorded storms gave rise to important economic losses and damages in the Gulf of Cadiz (Ballesta et al., 1998; Reyes et al., 1999; Anfuso and Gracia, 2005). The 2009/10 winter season was the stormiest season during the investigated time span, with 12 storm events equivalent to $614 \mathrm{~h}$
(26 d). The exceptional nature of the 2009/2010 winter under different climatic aspects was confirmed by several studies. In this sense, Cattiaux et al. (2010) observed as it was one of the coldest winter seasons since 1949 and Cohen et al. (2010) recorded extreme cold temperatures, snow precipitations and storms in most of the major population centres of the industrialized countries of the Northern Hemisphere.

Climatic anomalies were associated with an extreme persistence of negative phases of $\mathrm{AO}$ and $\mathrm{NAO}$ indices and an exceptional Northern Hemisphere mean atmospheric circulation episode (Wang et al. 2010) reflected by the distribution of the geopotential height anomalies at $500 \mathrm{mb}$ (Figure 7). This parameter exhibited a strong zonal hemispheric pattern, with anomalously high pressures over the pole during 2009/2010 (Figure 7). Such a distribution favoured the development of negative phases for the AO and NAO at the same time (Thompson and Wallace, 1998; L'Heureux et al., 2010). Similar results were recorded by Cohen et al. (2010) and 

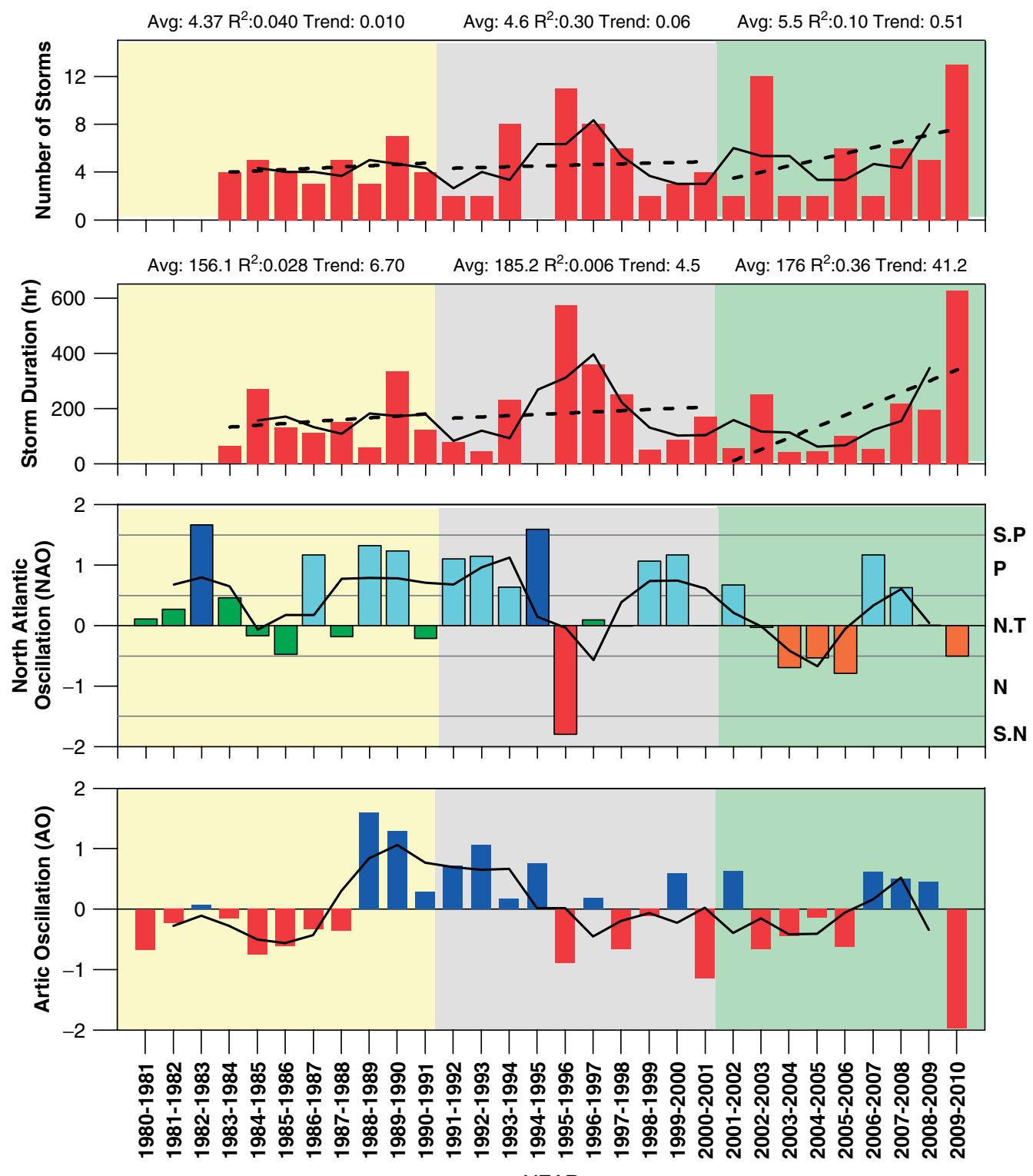

YEAR

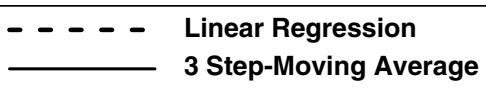

Figure 8. Yearly values of number of storms, storm duration, North Atlantic Oscillation (NAO) and Arctic Oscillation (AO) phases. Average (Avg), Root mean square $\left(r^{2}\right)$, lineal regression and the three step moving average also presented. NAO phases: SN, strong negative; N, negative; NT, neutral; P, positive; SP, strong positive.

L'Heureux et al. (2010) which highlighted that the negative AO phase of December 2009 was a record result of an unusual occurrence of two troposphere-stratosphere coupling events (NAO-AO) that occurred more rapidly than usual and in quick succession. Similar patterns of circulation and AO-NAO values (Figures 6 and 7) were recorded during the 2005/06, 1995/96, 1987/88 and 1963/64 winter seasons. These years were characterized by a high number of storms, great storm durations and a great amount of reported coastal damage (RangelBuitrago and Anfuso, 2011a).

Lastly, considering the decadal behaviour of annual values of $\mathrm{AO}$ and NAO indices, positive values were recorded during the past three decades (Figure 8). The 1980s were characterized by the general predominance of positive NAO phases, which specifically ranged from neutral to strong positive phases. The AO presented clear negative phases from 1980 to 1987 and positive ones from 1987 to 1994. Considering storminess, the 1980s can be classified as a period of 'calm' due to the low recorded condition in wave heights and storminess (35 storms).

In the 1990s, NAO and AO indices presented the predominance of positive phases, 1995 being the only year that recorded strong negative phases. During the 1990s, the teleconnection behaviour patterns and generally low storm activity, coincided with analyses performed by WASA (1998) in the northeast Atlantic coast, 
Ferreira et al. (2009) and Almeida et al. (2011) in Portugal and Rangel-Buitrago and Anfuso (2011a) in the Gulf of Cadiz. Finally, 2000-2009 was characterized by cyclic behaviour of both NAO and AO indices, as well as wave climates and storminess that showed extreme conditions between 2002 and 2003 and low energy conditions from 2004 to 2007.

\section{Conclusions}

Coastal erosion and flooding, increased by climatic change-related processes, represent a great threat to human activities and settlements developed along the World's coastlines especially because human pressure and occupation in such environments have been growing considerably in recent decades. The Cadiz coastal area includes different human settlements and natural environments, essentially large sandy beaches of great economic interest because of tourism-related activities. In past decades, beach reduction and loss of attractiveness were related to elevated coastal retreat rates basically linked to the impact of winter storms since sea level variations did not show a clear trend. Large amounts of money were spent counteracting coastal retreat by using beach nourishment works and hard engineering structures.

An important step towards reducing and preventing beach erosion and infrastructure damage is to understand and characterize wave climate and coastal processes, e.g. past and future trends. Understanding seasonal and annual wave climate behaviour is crucial in erosion prevention, as well as assessing beach response, cyclic variance and evolution. These are key issues in distinguishing real erosive trends from natural alternating erosion/accretion phases. Consequently, the applied methodology enables the characterization of wave climate, e.g. seasonal and annual periodicity, and storm events according to energy. This makes it simple and objective, while data can be easily compared with similar datasets from elsewhere.

In particular, wave climate and storm classes' distribution evidenced a clear seasonal trend in Cadiz area. Classes I and II (weak and moderate events) were observed along the entire winter season which covered the October to March period, class III events characterized the November to March period and classes IV and $\mathrm{V}$ (severe and extreme) events were recorded only in December and January, with January being the stormiest month. Wave climate and storminess during the 27 year period did not show a clear trend. This contradicted the forecast general increase in the number and intensity of storms in many oceans around the World and specifically the Northern Hemisphere, due to climate change. Storminess presented a cyclic behaviour which occurrence probability varied from $96 \%$ for class I to $3 \%$ for class $\mathrm{V}$. The return period for class $\mathrm{V}$ was 25 years and ranged from 6 to 8 year for storms belonging to classes III and IV, e.g. significant and severe events. Observations broadly confirmed results recorded at mid and low latitudes of the Northern Hemisphere and at other locations of the Cadiz Gulf, in this sense pointing to a broad homogeneity of regional wave climate.

Efforts in the direction of storm characterization and prediction should also point to the determination of the general climatic conditions for their formation, e.g. the comprehension of general atmospheric circulation systems linked to the teleconnection patterns. In the Cadiz area, storm distribution appeared linked to negative phases of $\mathrm{AO}$ and NAO indices. Even if further investigation is needed, it was highlighted that a great number of storms, larger storm duration and higher values of Storm Power Index were only observed when neutral to strong negative AO and NAO phases there were at the same time and/or when occurred an abrupt change of $\mathrm{AO}$ and NAO phases, i.e. they moved from a positive phase to a negative phase without passing through a neutral phase. Hence, accurate short-term predictions of AO and NAO indices might represent valuable predictive techniques to forecast storm events, e.g. establishing early and warning systems in order to reduce the impacts of energetic erosive events.

\section{Acknowledgements}

This work is a contribution to the RESISTE Research Project (CGL2008-00458/BTE, supported by the Spanish Ministry of Science and Technology and by European Funds for Regional Development - F.E.D.E.R.) and to the Andalusia P.A.I. Research Group no. RNM-328. Thanks to Puerto del Estado (Spanish Ministry of Public Works) for offshore wave data records. This work has been partially developed at the Centro Andaluz de Ciencia y Tecnología Marinas (CACYTMAR), Puerto Real (Cadiz, Spain).

\section{References}

Allan JC, Komar PD. 2000. Are ocean wave heights increasing in the eastern North Pacific?. EOS, Transactions of the America Geophysical Union 47: 561-567.

Allan R, Tett S, Alexander L. 2009. Fluctuations in autumn - winter severe storms over the British Isles: 1920 to present. International Journal of Climatology 29: 357-371.

Almeida LP. Ferreira O Vousdouskas MI. Dodet G. 2011. Historical variation and trends in storminess along the Portuguese Southcoast. Natural Hazards Earth Systems. Science 11: 2407-2417.

Andrade C, Trigo RM, Freitas MC, Gallego MC, Borges P, Ramos AM. 2008. Comparing historic records of storm frequency and the North Atlantic Oscillation (NAO) chronology for the Azores region. The Holocene 15(5): 745-754.

Anfuso G, Gracia FJ. 2005. Morphodynamic characteristics and short term evolution of a coastal sector in SW Spain: implications for coastal erosion management. Journal of Coastal Research 21(6): 1139-1153.

Anfuso G, Dominguez L, Gracia FJ. 2007. Short and medium-term evolution of a coastal sector in Cadiz, SW Spain. Catena 70: 229-242.

BACC Author Team. 2008. Assessment of Climate Change for the Baltic Sea Basin. Springer-Verlag: Berlin.

Bacon S, Carter DJT. 1991. Wave climate changes in the North Atlantic and North Sea. International Journal of Climatology 11: 545-558.

Ballesta M, Morales J, Acosta EA. 1998. Efecto erosivo de los temporales del invierno 1995-1996 sobre la playa de Mazagon (Huelva, SO España): influencia de las construcciones costeras. Revista de la Sociedad Geológica de España 11(3-4): 285-296. 
Barnston AG. Livezey RE. 1987. Classification, seasonality and persistence of low-frequency atmospheric circulation patterns. Monthly Weather Review 15: 1083-1126.

Barr S. 2004. Port beach Coastal Erosion Study, Technical Report 427. Department for planning and infrastructure: Fremantle.

Bell GD, Janowiak JE. 1995. Atmospheric circulation associated with the Midwest floods of 1993. Bulletin of American Meteorological Society 5: 681-695.

Benavente J, Del Río L, Anfuso G, Gracia, FJ, Reyes JL. 2002. Utility of morphodynamic characterization in the prediction of beach damage by storms. Journal of Coastal Research SI36: 56-64.

Boashash B. 2003. Time-Frequency signal Analysis and Processing: A Comprehensive Reference. Elsevier Science: Oxford.

Bromirski PD, Flinck RE, Cayan DR. 2003. Storminess variability along the California coast 1858-2000. Journal of Climate 16(6): 982-993.

Carter DJT, Draper L. 1988. Has the north-east Atlantic become rougher? Nature 332: 494.

Cattiaux J, Vautard R, Cassou C, Yiou P, Masson-Delmotte V, Codron F. 2010. Winter 2010 in Europe: a cold extreme in a warming climate. Geophysical Research Letters 37: L20704, DOI: 10.1029/2010GL044613.

Chen WY, Van den Dool H. 2003. Sensitivity of teleconnection patterns to the sign of their primary action center. Monthly Weather Review 131: 2885-2899.

Cohen J, Foster J, Barlow M, Saito K, Jones J. 2010. Winter 2009-2010: a case study of an extreme Arctic Oscillation event. Geophysical Research Letters 37: L17707, DOI: 10.1029/ 2010GL044256.

Coles S. 2001. An Introduction to Statistical Modeling of Extreme Values. Springer: London.

Cook NJ. 2004. Confidence limits for extreme wind speeds in mixed climates. Journal of Wind Engineering and Industrial Aerodynamics 92: $41-51$.

Dailidiene I, Davuliene L, Kelpsaite L, Razinkovas A. 2011. Analysis of the climate change in Lithuanian coastal areas of the Baltic Sea. Journal of Coastal Research 28(3): 557-569, DOI: 10.2112/JCOASTRES-D-10-00077.1.

Dodet G, Bertin X, Taborda R. 2010. Wave climate variability in the North-East Atlantic Ocean over the last six decades. Ocean Modeling 31: $120-131$.

Dolan R, Davis RE. 1992. An intensity scale for Atlantic coast northeast storms. Journal of Coastal Research 8: 352-364.

Dolan R, Lins H, Hayden B. 1989. Mid-Atlantic coastal storms. Journal of Coastal Research 4: 417-433.

Donat M, Leckebusch GC, Pinto JG, Ulbrich U. 2010. European storminess and associated circulation weather types: future changes deduced from a multi-model ensemble of GCM simulations. Climate Research 42: 27-43.

Dorsch W, Newland T, Tassone D, Tymons S, Walker D. 2008. A statistical approach to modeling the temporal patterns of ocean storms. Journal of Coastal Research 24(6): 1430-1438.

Dupuis H, Michel D, Sottolichio A. 2006. Wave climate evolution in the Bay of Biscay over two decades. Journal of Marine Systems $\mathbf{6 3}$ : $105-114$.

Eliot IG, Clarke DJ. 1986. Minor storm impact on the beach face of a sheltered sandy beach. Marine Geology 73(1-2): 61-83.

Esbensen SK. 1984. A comparison of intermonthly and interannually teleconnection in the $700 \mathrm{mb}$ geopotential height field during the Northern Hemisphere winter. Monthly Weather Review 112: 2016-2032.

Esteves LS, Williams JJ, Brown JM. 2011. Looking for evidence of climate change impacts in the eastern Irish Sea. Natural Hazards and Earth System Sciences 11: 1641-1656.

Ferreira O, Vousdoukas MV, Ciavola P. 2009. MICORE Review of Climate Change Impacts on Storm Occurrence. MICORE: Florence.

Gallego MC, Garcia JA, Vaquero JM. 2005. The NAO signal in daily rainfall series over the Iberian Peninsula. Climate Research 29(2): $103-109$.

Goda Y. 1988. On the methodology of selecting design wave height In Proceedings of the twenty-first coastal engineering conference. Malaga, Spain.

Goel NK, Burn DH, Pandey MD, An Y. 2004. Wind quartile estimation using a pooled frequency analysis approach. Journal of Wind Engineering and Industrial Aerodynamics 92: 509-528.

Gringoten LL. 1963. A plotting rule for extreme probability paper. Journal of Geophysical Research 68(3): 813-814.
Hanson H, Larson M. 2008. Implications of extreme waves and water levels in the southern Baltic sea. Journal of Hydraulic Research 46(2): 292-302.

Hatzaki M, Flocas HA, Maheras P, Asimakopoulos DN, Giannakopoulos C. 2006. Study of future climatic variations of a teleconnection pattern affecting Eastern Mediterranean. Global NEST Journal 8(3): 195-203.

Higgins RW, Leetma A, Kousky VE: 2002. Relationships between climate variability and winter temperature extremes in the Unites States. Journal of Climate 15: 1555-1572.

Hurrell JW. 1995. Decadal trends in the North Atlantic Oscillation: regional temperatures and precipitation. Science 269: 676-679.

Hurrell, JW, Deser C. 2009. North Atlantic climate variability: the role of the North Atlantic Oscillation. Journal of Marine Systems 78(1): $28-41$.

Jenkinson AF. 1955.. The frequency distribution of the annual maximum (or minimum) values of meteorological elements. Quarterly Journal of the Royal Meteorological Society 81: 158-171.

Jenks GF, Caspal FC. 1971. Error on choropletic maps: definition, measurement, reduction. Annals of the Association of American Geographers 61(2): 217-244.

Jones A, Phillips M. 2011. Disappearing Destinations. CABI: Wallingford.

Keim BD, Muller RA, Stone GW. 2004. Spatial and temporal variability of coastal storms in the North Atlantic Basin. Marine Geology 210: 7-15.

Kelpsaite L, Dailidiene I, Soomere T. 2011. Changes in wave dynamics at the south-eastern coast of the Baltic proper during the 1993-2008. Boreal Environmental Research 16: 220-232.

Komar P, Allan JC. 2008. Increasing hurricane-generated wave heights along the U.S. East Coast and their climate controls. Journal of Coastal Research 24(2): 479-488.

L'Heureux M, Butler A, Jha A, Kumar A, Wang W. 2010. Unusual extremes in the negative phase of the Arctic Oscillation during 2009. Geophysical Research Letters 37: L10704, DOI: 10.1029/2010GL043338.

Lemm AJ, Hegge BJ, Masselink G. 1999. Offshore wave climate, Perth (Western Australia): 1994-1996. Marine and Freshwater Research 50: 95-102.

Li F, Roncevich L, Bicknell C, Lowry R, Ilich K, 2011. Interannual variability and trends of storminess Perth, 1994-2008. Journal of Coastal Research 27(4): 738-745.

Lozano I, Devoy RJN, May W, Andersen U. 2004. Storminess and vulnerability along the Atlantic coastlines of Europe: analysis of storm records and of a greenhouse gases induced climate scenario. Marine Geology 210: 205-225.

Mao R, Gong D, Bao J, Fan Y. 2011. Possible influence of Arctic Oscillation on dist storm frequency in North China. Journal of Geographical Sciences 21(2): 207-218.

Marcos M, Tsimplis M. 2008. Coastal sea level trends in Southern Europe. Geophysical Journal International 175: 70-82.

Marcos M, Puyol B, Woppelmann G, Herrero C, Garcia-Fernandez MJ. 2011. The long sea level record at cadiz (southern Spain) from 1880 to 2009. Journal of Geophysical Research 116: C1200, 10 pp, DOI: 10.1029/2011JC007558.

Matulla C, Schoner W, Alexandersson H. 2007. European storminess: late nineteenth century to present. Climate Dynamics 31: 125-130.

Mendoza ET, Jimenez JA. 2008. Coastal storm classification on the Catalan littoral (NW Mediterranean). Ingeniería Hidráulica en México 23(2): 23-34.

Menéndez M, Méndez F, Losada I, Medina R, Abascal A. 2004. Variaciones del régimen extremal del clima marítimo en el litoral español en el periodo 1958-2001. In El Clima entre el Mar y la Montaña, Concha D, Garcia J, Alvarez D. (eds). Universidad de Cantabria: Santander.

Meyer-Arendt K. 2011. Grand Isle, Louisiana: a historic US Gulf Coast Resort Adapts to Hurricanes, Subsidence and Sea Level Rise. In Disappearing Destinations, Jones A, Phillips M. (eds). CABI: Wallingford, 203-217.

Moritz H, Moritz H. 2006. Evaluating extreme storm power and potential implications to coastal infrastructure damage, Oregon Coast USA. In $9^{\text {th }}$ International Workshop on Wave Hindcasting and Forecasting. Victoria, Canada.

Morton I, Bowers J, Mould G. 1997. Estimating return period wave heights and winds speeds using a seasonal point process model. Coastal Engineering 26: 251-270.

Muñoz JJ, Enriquez J. 1998. Dinámica litoral de una unidad fisiográfica completa: Sanlúcar-Rota. Revista de Obras Publicas 3375: 34-44. 
Muñoz JJ, Lopez B, Gutierrez JM, Moreno L, Cuenca G. 2001. Cost of beach maintenance in the Gulf of Cadiz (SW Spain). Coastal Engineering 42: 143-153.

Muñoz-Diaz D, Rodrigo FS. 2003. Effects of the North Atlantic oscillation on the probability for climatic categories of local monthly rainfall in southern Spain. International Journal of climatology 23(4): 381-397.

O'Connor M, Cooper AJW, Jackson DWT. 2011. Decadal behavior of tidal inlet-associated beach systems, northwest Ireland, in relation to climate forcing. Journal of Sedimentary Research 81: 38-51.

Pattiaratchi C, Elliot M. 2008. Sea level variability in south-west Australia: from hours to decades. In Proceedings of the $31^{\text {st }}$ ASCE International Conference on Coastal Engineering. Hamburg, Germany.

Phillips M. 2008. Consequences of short-term changes in coastal processes: a case study. Earth Surface Processes and Landforms 33: 2094-2107.

Phillips M, Crisp S. 2010. Sea level trends and NAO influences: the Bristol Chanel/Seven Estuary. Global and Planetary Change 73: 211-218.

Pinto J, Zacharias S, Fink AH, Leckebush GC, Ulbrich U. 2009. Factors contributing to the development of extreme North Atlantic cyclones and their relationship with the NAO. Climate Dynamics 32: $711-737$.

Plomaritis T, Anfuso G, Rangel-Buitrago N, Benavente J, Del Rio L. 2009. Erosion and accretion patterns in different morphodynamic beach states in Cadiz (SW Spain). In $7^{\text {th }}$ International conference on geomorphology. Melbourne, Australia.

Plomaritis T, Del Rio L, Benavente J, Valladares M. 2010. Storm thresholds for the Spanish Gulf of Cadiz coast. Geophysical Research Abstracts 12: 10781.

Rangel-Buitrago N, Anfuso G. 2011a. An application of Dolan and Davis (1992) classification to coastal storms in SW Spanish littoral. Journal of Coastal Research SI64: 1891-1895.

Rangel-Buitrago N, Anfuso G. 2011b. Coastal storm characterization and morphological impacts on sandy coasts. Earth Surface Process and Landforms 36(15): 1997-2010.

Rao AR, Hamed KH. 2000. Flood Frequency Analysis. CRC press: Boca Raton.

Reyes JL, Martins JT, Benavente J, Ferreira O, Gracia FJ, Alveriño-Dias JM, López-Aguayo F. 1999. Gulf of Cadiz beaches: a comparative response to storm events. Boletin del Instituto Español de Oceanografía 15(1-2): 221-228.

Rodriguez A, Ruiz F, Caceres LM, Rodriguez J, Pino R, Muñoz JM. 2003. Analysis of the recent storm record in the south western Spanish coast: implications for littoral management. The Science of the Total Environment 303: 189-201.

Rogers JC, McHugh MJ. 2002. On the separability of the North Atlantic Oscillation and Arctic Oscillation. Climate Dynamics 19: 599-608.

Schmith T, Kass E, Li TS. 1998. Northeast Atlantic winter storminess 1875-1995 re-analyzed. Climate Dynamics 14: 529-536.
Soomere T. 2008. Extremes and decadal variations of the northern Baltic seawave conditions. In Extreme Ocean Waves, Pelinovsky E, Kharif C. (eds). Springer-Verlag: Berlin, 193-157.

Suursaar U. 2010. Waves, currents and sea level variations along the Letipea-Sillamae coastal section of the southern Gulf of Finland. Oceanologia 52(3): 391-416.

Thomas T, Phillips MR, Williams AT, Jenkis RE. 2011. Short-term beach rotation, wave climate and the North Atlantic Oscillation (NAO). Progress in Physical Geography 35(3): 333-352.

Thompson DWJ, Wallace JM. 1998. The Artic Oscillation signature in the wintertime geopotential height and temperature fields. Geophysical Research Letters 25: 1297-1300.

Thompson DWJ, Wallace JM, Hegerl GC. 2000. Annular modes in the extratropical circulation. Part II: trends. Journal of Climate 13: 1018-1036.

Trigo RM, Osborn TJ, Corte-Real J. 2002. The North Atlantic Oscillation influence on Europe: climate impacts and associated physical mechanism. Climate Research 20: 9-17.

Türkes M, Erlat E. 2008. Influence of the Arctic Oscillation on the variability of winter mean temperatures in Turkey. Theoretical and Applied Climatology 92: 75-85.

Wallace JM. 2000. North Atlantic Oscillation/annular mode: two paradigms - one phenomenon. Quarterly Journal of the Royal Meteorological Society 126: 791-805.

Wallace JM, Gutzler DS. 1981. Teleconnections in the geopotential height field during the Northern Hemisphere winter. Monthly Weather Review 109: 784-812.

Wang S, McGrath R, Hanafin JA, Lynch P, Semmler T, Nolan P. 2008. The impact of climate change on storm surges over Irish waters. Ocean Modeling 25: 83-94.

Wang C, Liu H, Lee S. 2010. The record-breaking cold temperatures during the winter of 2009/2010 in the Northern Hemisphere. Atmospheric Science Letters 11: 161-168.

WASA 1998. Changing waves and storms in the northeast Atlantic. Bulletin of the American Meteorological Society 79: 741-760.

Wettstein JJ, Mearns LO. 2002. The influence of the North AtlanticArctic Oscillation on mean, variance and extremes of temperature in the northeastern United States and Canada. Journal of Climate 15: 3586-3600.

WMO (World Meteorological Organization). 1995. The Global Climate System Review. Climate System Monitoring1991-1993. WMO: Geneva.

Xoplaki E. 2002. Climate Variability Over the Mediterranean, $\mathrm{PhD}$ thesis, University of Bern, Switzerland.

Zhang K, Douglas BC, Leatherman SP, 2000. Twentieth-century storm activity along the U.S. East Coast. Journal of Climate 13 $1748-1761$.

Zhou S, Miller AJ, Wang J, Angell JK. 2001. Trends of NAO and $\mathrm{AO}$ and their associations with stratospheric processes. Geophysical Research Letters 28: 4107-4110.

Zielinski G. 2002. A classification scheme for winter storms in the Easter and central United States with an emphasis on Nor'easters. Bulletin of the American Meteorological Society 83: 37-51. 